Ethos: Jurnal Penelitian dan Pengabdian kepada Masyarakat, Vol 8, No.1, Juni 2019: 89-94

\title{
Penjualan Online Ikan Asin Sebagai salah Satu Usaha Meningkatkan Pendapatan Masyarakat Nelayan Bagan Deli
}

\author{
${ }^{1}$ Sri Wahyuni, ${ }^{2}$ Mesra B, ${ }^{3}$ Akhyar Lubis, ${ }^{4}$ Supina Batubara \\ 1,2,3,4 Universitas Pembangunan Panca Budi, Medan, Sumatera Utara, Indonesia

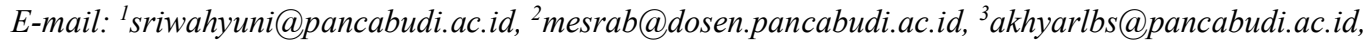 \\ ${ }^{4}$ supinabatubara@pancabudi.ac.id
}

\begin{abstract}
The Target that is wanted to be achieved from the Program Kemitraan Masyarakat Stimulus (PKMS) is the application of the sale of salted fish online (ecomerce) at the Fisherman Society. Bagan Deli that has a search for the people of fishermen, if the fish is not sold or discharged, the wives of fishermen process it into salted fish. However, the salty fish market has constraints that are only limited to traditional markets in Bagan Deli and to brokers that are selling prices very cheap. The main Target of this program is to implement good online sales with existing applications such as Shopee, Buka Lapak and social media. Training and mentoring was directly acquired by the team to the UKM Desi group of the salty fish-making fishermen in Bagan Deli fisherman who would later become a pilot for another UKM group of salted fish processing. The result of this activity is that the group of salty fish makers know and apply the online salty fish distribution (e-comerce). Where before sales are made only limited to traditional sales in Bagan Deli market.
\end{abstract}

Keywords: E-Comerce, Salted Fish, UKM

Abstrak. Target yang ingin dicapai dari Program Pengabdian Masyarakat Stimulus (PKMS) adalah penerapan penjualan ikan asin secara online (e-comerce) pada Masyarakat Nelayan Bagan Deli. Bagan Deli yang mayorita mata pencarian penduduknya Nelayan, jika ikan tidak laku atau habis dijual maka para istri nelayan mengolahnya menjadi ikan asin. Namun penjualanan ikan asin memiliki kendala yaitu penjualan hanya sebatas pasar tradisional di Bagan Deli dan kepada tengkulak yang mengakibatakan harga yang dijual sangat murah. Target utama program ini yaitu mengimplementasikan penjualan secara online baik dengan aplikasi yang sudah ada seperti shopee, buka lapak atau pun melalui media sosial. Pelatihan dan pendampingan dilakuakn langsung oleh tim kepada UKM Desi kelompok para istri nelayan pembuat ikan asin di Bagan Deli nelayan yang nantinya akan menjadi percontohan bagi kelompok UKM lain pengolah ikan asin. Hasil dari kegiatan ini adalah para kelompok UKM pembuat ikan asin mengetahui dan menerapkan penjulanan ikan asin secara online (e-comerce). Dimana sebelum penjualan dilakukan hanya sebatas penjualan tradisional di pasar bagan Deli.

Kata kunci: Penjualan Online, UKM, Ikan Asin 


\section{Pendahuluan}

Bagan Deli adalah salah satu daerah yang berada di Pesisir Timur Sumatera Utara. Karena wilayah Bagan Deli adalah pesisir pantai maka mayoritas mata pencarian penduduknya adalah Nelayan. Masyarakat Bagan Deli mendapatkan penghasilan dari menjaul hasil ikan tangkapan. Ikan yang tidak habis terjual maka oleh para istri nelayan diolah menjadi ikan asin. UMKM Desi adalah salah satu dari banyak pengolah ikan menjadi ikan asin di Bagan Deli seperti gambar 1. Hasil ikan di peroleh dari kelompok nelayan yang kemudian dibeli dari nelayan di pasar penjualan ikan seperti gambar 2. Sampai saat ini tenaga kerja yang berkerja sekitar 3-5 orang dan pelanggannya masih terbatas di sekitar desa Bagan Deli atau seputaran Belawan. Gambaran sistem penjualan saat ini hanya dari mulut ke mulut dan pasar tradisional. Untuk produksinya saat ini masih menggunakan peralatan tradisional yang jauh dari teknologi, sedangkan tidak menggunakan kemasan hanya kantong plastik biasa seperti ditunjukan pada Gambar 3.

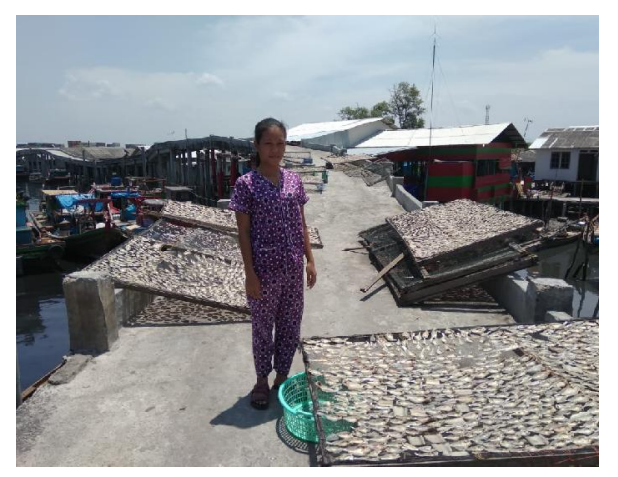

Gambar 1. UKM Desi Pembuat ikan asin

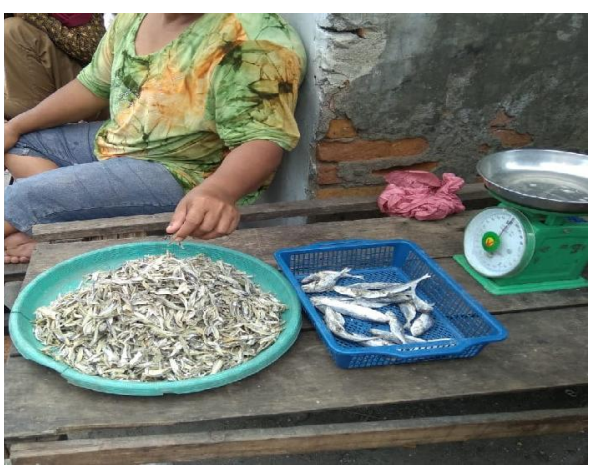

Gambar 2. Penjualan Ikan Asin di pasar tradisional

\section{Permasalahan Kelompok Mitra}

Potensi peluang bagi UKM di Bagan Deli khususnya UKM Desi sebenarnya sangat besar mengingat di Bagan Deli mayoritas berprofesi sebagai nelayan dan mudahnya mendapatkan bahan baku berupa ikan, namun beberapa kelemahan perlu diperhatikan adalah sebagai berikut :

1. Keterbatasan Pemasaran

Pemasaran yang umumnya dilakukan oleh pengolah ikan asin adalah sebatas hanya pemasaran lokal di Bagan Deli dan di jual ke tengkulak sehingga menyebabkan ikan asin yang dijual sangat murah, begitu juga persaingan dipasar domestik dengan produk yang serupa oleh pengusaha sekala besar dan produk impor, maupun dipasar ekspor. Kurangnya pemanfaatan media internet sebagai media promosi produk.

2. Keterbatasan Pemanfaatan Teknologi.

Keterbatasan pengetahuan dan pemanfaatan teknologi masih sangat kurang mereka miliki, sehingga teknologi masih menggunakan teknologi yang sifatnya manual. Masih minimnya pengengetahuan penggunaan teknologi 
dan keterbatasan sumber daya manusia yang terlibat didalamnya sangat mempengaruhi, terutapa dalam aspekaspek pemanfaatan teknologi untuk pemasaran produk dan penjualan produk secara online atau $e$-comerce.

\section{Penjulan Online}

Penjualan Online atau biasa disebut e-comerce adalah proses jual beli yang dilakukan dengan bantuan internet kemudian website digunakan sebagai penghubung dalam melakukan transaksi tersebut. (Nurhafifah Matondang, 2018). Manfaat Penjualan online adalah sebagai berikut :

1. Dapat meningkatkan pangsa pasar menjadi lebih luas.

2. Menurunkan biaya operasional, seperti sewa toko, karyawan, biaya iklan atau promosi produk.

3. Melebarkan jangkauan penjualan.

4. Meningkatkan Customer Loyalty.

5. Meningkatkan Management.

Menurut Deddy Prihadi dala jurnal yang berjudul "Pengaruh Kemampuan e-comerce dan Promosi Di Media Sosial TerhadapKinerja Pemasaran" pengaruh e-comerce dan media sosial sangat signifikan terhadap kinrerja pemasaran pedagang. Dimana promosi dengan media sosial dan penjuajualan secara e-comerce dapat meningkatkan penjualan dari suatu produk penjualan.

\section{Media Sosial}

Media Sosial yaitu media berbasis online yang mensuport seseorang melakukan interaksi sosial.
Media sosial dibantu dengan teknologi yang berbasis web yang mengubah komunikasi menjadi dialog interaktif. Contoh media sosial Whatsapp, BBM, Facebook, Youtube, Twitter, Wikipedia, Blog.

Media Sosial memiliki peranan penting dalam menaikan promosi dan pengenalan produk dengan biaya yang relatif hemat. Media sosial dapat dengan mudah dijadikan promosi dengan perantara internet.

\section{Metode Penelitian}

Dalam mewujudkan program pengabdian maka diawali dengan pendekatan kepada masyarakat Bagan Deli melalui sosisalisasi, sosialisasi juga dilakukan kepada pihak pemerintahan yaitu bapak lurah Bagan Deli, Bapak Zul Ari, SP dimana pihak kelurahan berkontribusi besar dalam pelaksaaan program, kantor keluaran juga digunakan sebagai tempat pelatihan, worksop dan sekaligus pendampingan kepada para ibu ibu rumah tangga pembuat ikan asin. Setelah sosialisasi dilakukan pelatihan penjualanan ikan asin secara online kepada mitra. Pada saat kegiatan ini dilkaukan juga diskusi serta tanya jawab langssung oleh Tim Pengabdaian Masyarakat Stimulus. Selanjutnya akan dilakukan simulasi terhadap penjualan ikan asin secara online, baik menggunakan alikasi penjualan online seperti sophie dan buka lapak ataupun menggunakan media sosial seperti facebook dan Instagram. 
Sosialisasi Kepada Masyarakat Bagan Deli dan Bapak Lurah Bagan Deli

Pengenalan Penjualan Online dan Pentingnya penjualan Online

\section{Pelatihan Promosi pada Aplikasi}

Penjualan Online dan Media Sosial

Praktek secara langsung dan Pendampingan cara mengupload produk di Sohopee dan media sosial

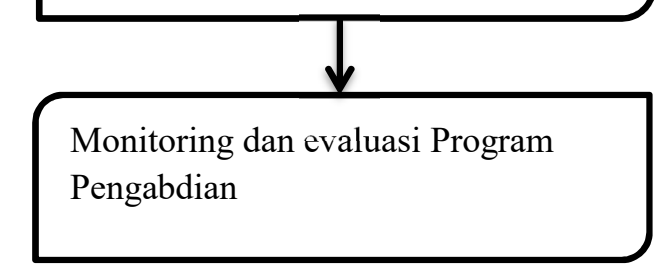

\section{Gambar 3. Metode Pendekatan pelaksanaan PKMS}

\section{Hasil dan Pembahasan}

Penerapan penjualanan online ikan asin kelompok UKM Bagan Deli dalam meingkatkan penjualan ikan asin yang berdampak pada peningkatan pendapatan masyarakat Bagan Deli, dengan meningkatkan pendapatan juga kesejahtraan masyarakat nelayan Bagan Deli. Program diawali dengan sosialisasi kepada pelaku UKM yaitu para istri pembuat ikan asin. Persiapan dilakukan dengan pendampingan pengurusan $\mathrm{P}$ IRT, mendesain brand ikan asin, pembelian alat vacum sealer, dan plastik pembungkus kemasan ikan asin yang baik agar ikan menjadi lebih menarik dan tahan lama. Sosialisasi juga dilakukan kepada pihak kelurahan Bagan Deli dimana kantor kelurahan Bagan Deli adalah sebagai tempat workshop dan praktek secara langsung. Pada Kesempatan Ini dijelaskan tentang penjualan secara On-line, baik menggunakan aplikasi e-comerce yang sudah ada seperti shopee dan buka lapak ataupun menggunakan media sosial, tak lupa tim juga menyampaikan tentang peranan dan pentingnya media sosial dalam melakukan promosi terhadap produk ikan asin. Kegiatan ini juga dilakukan sesi tanya jawab dan praktek secara langsung mengupload produk pada aplikasi e-comerse shopee.

1. Tampilan Aplikasi Penjualan Di Shopee dan Pelatihan Penjualan Online

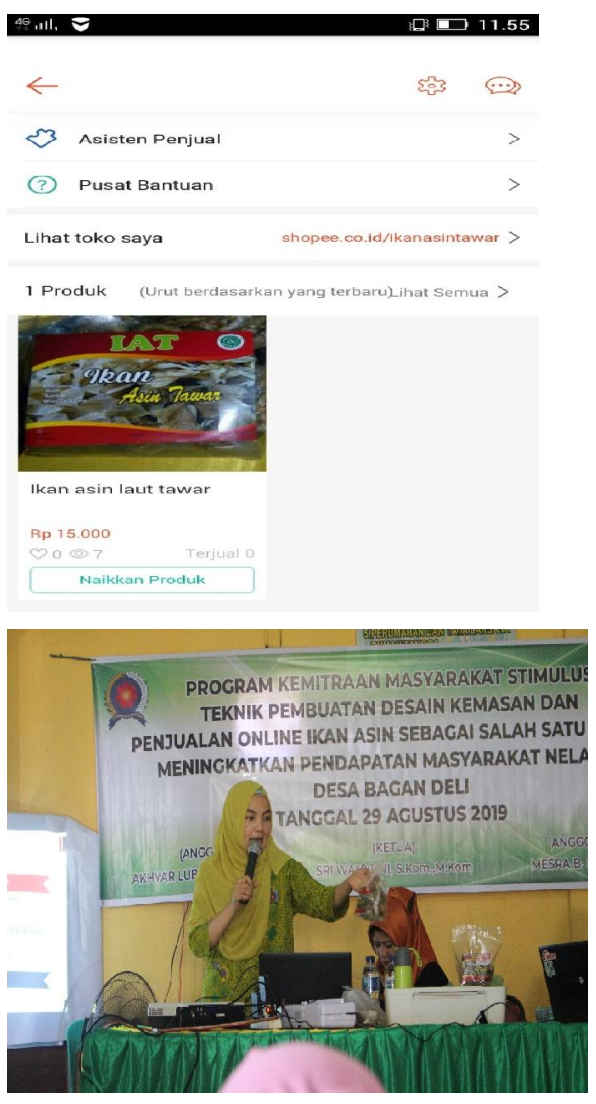


2. Pengabdian Kepada Masyarakat Penjuatan Online Ikan ASin Bagan Deli

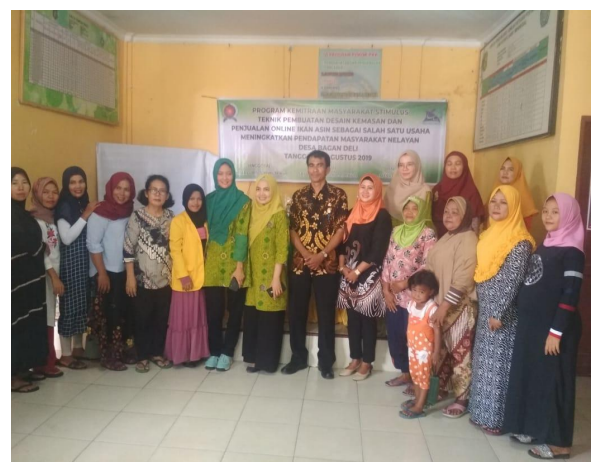

\section{Kesimpulan}

Kesimpulan dan saran dari kegiatan Teknik Pembuatan Desain Kemasan dan Penjualanan Secara Online Ikan Asin Sebagai Salah satu Usaha Meningkatkan Pendapatan Masyarakat Nelayan Bagan Deli sebagai berikut :

1. Para UKM Bagan Deli mengenal aplikasi penjulan online dan media sosila sebagai media promosi dan ikan asni Bagan Deli untuk memperluas jangkauan promosi dan penjualan.

2. Pelatihan dan Pendampingan penjualan ikan Asin kepada UKM Desi dengan pelatihan menggunakan aplikasi, menambah ataupun mengubah produk pada aplikasi penjaulan online ataupun melakukan transaksi atau mengelola aplikasi sehingga mitra dapat mandiri menggunakan aplikasi penjualan online seperti shopee dan buka lapak.

3. Dengan melakukan pejualan secara online UKM Desi dapat memasarkan produk secara lebih luas dan global serta tidak lagi terikat oleh tempat dan waktu.

\section{Ucapan Terimakasih}

1. Terimakasih kepada Direktorat Riset dan Pengabdian Masyarakat (DRPM) Kementerian Riset, Teknologi, Dan Pendidikan Tinggi (Kemenristekdikti) yang telah memberikan bantuan dana untuk program Kemitraan Masyarakat Stimulus (PKMS) untuk pendanaan tahun 2019.

2. Terimakasih kepada Lembaga Penelitian dan Pengabdaian Masyarakat (LPPM) Universitas Pembangunan Panca Budi yang telah banyak memberikan bantuan dan dukungan sehingga Program ini dapat terealisasi.

3. Terimakasih kepada Kelurahan Bagan Deli dan Mitra yang terlibat dalam pelaksanaan program pengabdaian.

\section{Daftar Pustaka}

Nurhafifh Matondang, "Implementasi Sistem Penjualan Berbasis ECommerce Bagi Usaha Kecil Menengah Bojong Gede-Bogor". ETHOS Jurnal Penelitian dan Pengabdian. Vol.6 No.1 Januari 2018. Hal:30-38

Nurprapti Wahyu Widyastuti, "Meningkatkan Daya Saing Produk Usaha Mikro Melalui Desain Kemasan kelompok Usaha Produsen dan Retailer Makanan 'Kue Subuh"” Jurnal Pengabdian Masyarakat Ipteks. Vol.4 No.1 Juni 2018. Hal 1725 
94 | Sri Wahyuni, et al.

Deddy Prihadi, "Pengaruh Kemampuan e-comerce dan Promosi Di Media Sosial Terhadap Kinerja Pemasaran" Jurnal Manajemen dan Bisnis. Vol.3 No.1, Juni 2018. Hal.15-20

Heri Irawan, "Penerapan E-Commerce Berbasis Website Utuk Meningkatkan Pangsa Pasar Penjulana Keripik UD Aduhai Gampong Karangnyar Kecamatan Langsa Baro Kota Langsa" Seminar Nasional Teknik Industri, Lhokseumawe-Aceh, Agustus 2017. Hal 13-14

Marliana. 2012. Penerapan Agenda Pengingat Berbasis Aplikasi. Prosiding SnaPP 2014 Sains, Teknologi dan Kesehatan. Volume 3 Nomor 1, Tahun 2012. 